\title{
Features of sustainable economic development in the Central Asian countries
}

\author{
Natalia Brovko ${ }^{1}$, and Malik Borbugulov ${ }^{2}$ \\ ${ }^{1}$ SEIHPE Kyrgyz-Russian Slavic University named after the first President of the Russian Federation \\ B. N. Yeltsin, Bishkek, Kyrgyz Republic \\ ${ }^{2}$ International Ala-Too University, Bishkek, Kyrgyz Republic
}

\begin{abstract}
In this study there is an attempt to consider not only the consequences of climatic and technogenic changes in the Kyrgyz Republic, but also to develop some directions for solving these problems, taking into account the natural, economic and geopolitical capabilities of this country at the present stage. Within the framework of the study the issues of the impact of climate change associated with the reduction of fresh water, agricultural and crop production, as well as the problems of further use of traditional energy sources have been studied. These aspects are deeply covered as the Sustainable Development Goals under the auspices of the UN. According to the author, it is vitally important for the countries of the post-Soviet area to simultaneously find independent and nationally oriented directions and approaches to solve these problems, but without fail using the developments of the institutional base, the experience of the world community, as well as the advantages of regional integration. The main results consist in the development of a green development model related to the use of renewable energy sources at the present stage of development. The field of application of the results obtained is determined by the possibilities of including the main indicators of green development in strategic plans for socio-economic development and increasing the competitiveness of the national economy. The approach proposed by the authors allows, as a replenishment of lost energy sources in connection with climate warming and a decrease in water resources: proposals for the development of alternative sources of energy supply, the creation of solar and wind farms is proposed.
\end{abstract}

\section{Introduction}

Modern trends associated with technological, climatic changes have an impact on the further economic development of countries [1]. Over the past few decades, the world community has gone from a global discussion of the problems of preserving the natural environment, biological species and combating environmental pollution to the creation of a new green model of the economy, in which environmental protection is not considered as an anthropogenic load on the economy or a constraint to economic growth, but also as an engine of development. The concept of sustainable development was the first attempt to combine the goals of economic development with the need to include the natural environment in a single ecological and economical system. The basic principle of sustainable development assumes such a development in which the needs of the present generations are fully satisfied, 
while maintaining the ability of future generations to meet their needs taking into account the harmonious development of society, economy and nature. However, the ongoing degradation of the environment and, as a consequence, repeated environmental crises and natural disasters (floods, forest burning, degradation of land resources, etc.), which claim millions of human lives, causing irreparable damage to the natural environment and economy, have made the world community seriously think about the need to develop new principles on which the modern economy should be based. The turning point in the relevance and timeliness of the issue of abandoning the traditional model of economic development based on fossil energy sources, and the transition to a green economy was the world financial crisis in 2008. The same year, the United Nations Environment Program (UNEP) launched the Green Economy Initiative (GEI), which guides the scientific and expert community, responsible politicians and the world business elite to find mechanisms for transferring the world economy to an environmentally compatible way of development. If we add to this the crisis situation associated with the spread of the pandemic and the economic damage inflicted in tens of billions of US dollars, then the need for rational and effective use of the available natural resource potential will increase manifold. It should be noted that the concept of a green economy includes many ideas related to sustainable development issues. The sustainable development supposes a close interconnection of three subsystems - economic, social and environmental, then the concept of a green economy calls for harmonization and coherence between these components, which is acceptable to all countries regardless of their stage of economic development. According to the scientists of the Moscow State University S. N. Bobylev, P. A. Kiryushin, O. V. Kudryavtseva "new models of the economy in various studies are represented by the following interpretations: "green" economy, circular economy, low-carbon economy, bioeconomy, blue economy (the WB project), etc. New "hybrid" types are also emerging, for example, circular bioeconomy". [2] "Clean and equitable economic growth, which is an integral part of sustainable development, requires more efficient use of resources: "eco-efficiency" makes economic sense for business. [3]

According to the authors, a green economy is a strategic approach to formulating policies that lead to sustainable economic growth and social empowerment without harming the environment. The economy should serve society and maintain a healthy environment, not the other way around. It is necessary to use effective methods to reduce the negative impact of the economy on nature: minimization of the use of natural resources; reduction of waste from production and consumption; reuse of resources - "turning waste into income".

The most successful practices for promoting a green economy in post-Soviet countries are presented below:

- The EcoQolday project is a digital platform in Kazakhstan for the collection, processing, transportation and disposal of packaging waste (waste paper, plastic, glass and metal). The Coalition for a Green Economy and Development "G-Global" is one of the leading "green" public organizations in Kazakhstan and is a public provider of the Concept on Transition towards Green Economy.

- Kairakkum HPP Rehabilitation Project Phase II "Improving the Kairakkum HPP resilience to climate change" (Tajikistan). LLC "Technologies and Sabz" (Green Technologies) is a team of young engineers united by a common goal: "Expanding the use of innovative and environmentally friendly energy sources in Tajikistan."

- A plant for the production of environmentally friendly synthetic gasoline from natural gas, jointly implemented by the SC "Turkmengaz" and the companies Kawasaki Heavy Industries and Rönesans (Turkmenistan).

- "Green Economy through Green Universities" - Green Campus project at D. Serikbayev East Kazakhstan technical university (Kazakhstan).

It is also necessary to identify international examples of the successful application of tools of economic policy in environmental management: Austria - loans to industrial 
enterprises at $6 \%$ interest rate for a period of 10 years; Germany - preferential credit schemes, landfill tax, lubricating oil tax; Canada - soft loans for the construction and maintenance of communal sewerage systems and facilities; Netherlands, Finland, Italy, Mexico - tax on carbon emissions from fossil fuel combustion; Great Britain, Australia and several other countries - tax on the use of fuel and oil products; USA, Canada, Kazakhstan, Denmark, Italy, France, the Netherlands and a number of other countries - environmental insurance.

According to T.A. Selisheva - "in Russia and other EAEU countries, in order to achieve the "decoupling effect" changes in the state industrial and innovation policies and transformation of growth models are needed. A feature of the economies of the EAEU countries is that the main share of them is made up of industries with a large impact on the environment, and the GDP growth is achieved due to the extraction of minerals and manufacturing production of technological paradigms, and not due to the production of hightech products. A transition to the sixth technological paradigm is necessary, in which "green" technologies are priority and investments exceeds the investments of the fifth technological paradigm, which can be done only on condition of cooperation of financial resources of the EAEU states [4]. Thus, the strengthening of integration within the Eurasian Economic Union can contribute to the transition to the sixth technological paradigm and the formation of a "green" economy." [5]

Research methods. The methodological basis of the study is the works of scientists on the problems of institutional changes and state regulation of the green economy. The institutional system, as an integral system in the economy, has been studied at different levels: the level of the institutional environment; the level of institutional agreements; the level of behavior of individuals. In the process of analysis, the following research methods were used: analysis and synthesis, grouping, comparison, factorial, abstract-logical, analytical, monographic, method of expert assessments, economical and statistical analysis of the results.

Research results. To assess the status of the institutional environment of the green economy, more than 790 various documents for all five countries of Central Asian were studied. The ratified conventions by all five countries (Kazakhstan, Kyrgyzstan, Uzbekistan, Tajikistan, Turkmenistan): UN Framework Convention on Climate Change, Convention on Biological Diversity, Convention to Combat Desertification in Those Countries Experiencing Serious Drought and / or Desertification, Particularly in Africa, Vienna Convention for the Protection of the Ozone Layer, Convention on Access to Information, Public Participation in Decision-Making and Access to Justice in Environmental Matters, Convention on Wetlands of International Importance Especially as Waterfowl Habitat, Convention on International Trade in Endangered Species of Wild Fauna and Flora.

The most important condition for solving all the identified problems in the new realities of the Fourth industrial revolution is an institutional transformation. The emergence and diffusion of technologies of the Fourth industrial revolution and the areas of their application must be accompanied by appropriate institutions, standards and norms. The greatest importance is not the technologies themselves, but its impact on social and economic systems through norms, rules, expectations, goals, organizations and incentives that shape people's behavior - behavioral institutions. This also includes infrastructure, taking into account new technologies, providing flows of people and resources necessary for economic, political and social life [6].

The international legal documents regulating legal relations between countries in the area of environmental management are conventions, agreements, memorandums, declarations and other international legal acts that establish legal norms and national obligations for each participating country. One of the ways to implement the national obligations adopted under the conventions is to train executives, production managers, business managers in the skills of rational use of natural resources. In doing so, skills must be developed at the level of 
persuasion. This is the role and task of institutions to make the principles of rational use of natural resources massive in modern production and to obtain the expected effect.

The presence of indicators of the green economy at the national and regional levels makes it possible to monitor compliance with environmental and economic norms and interests in the countries of the region.

The level of use of the green economy is at a low level in the Central Asian region, i.e. of the five main indicators only the indicator of the availability of water resources has a more positive value. The analysis showed that Tajikistan and Kyrgyzstan are leaders in terms of water resources and renewable energy sources in the region, as well as leaders in its use. The total potential of renewable energy sources in Tajikistan accounts for 5\% and Kyrgyzstan $11 \%$. The strategic direction for the development of a green economy in the region is the development of renewable energy sources. The latter is closely related to the rational use of hydro resources as the main renewable energy source in Central Asia [7].

The rational use of the water and energy potential of Central Asia, as a source of green energy, is one of the pressing problems of the development of the economies of each individual country, but also of the balanced and integrated development of the economy of the Central Asian region. The latter is connected, on the one hand, with ensuring the country's energy security, since energy is the foundation for the development of all spheres of the economy, industrialization and modernization of industry, agriculture, transport and other spheres of the economy of the countries of the region, and on the other hand, ensuring the needs of irrigation, agriculture and population and, more importantly, access of the population and economy of the region to clean and green energy

The main directions of economic development of the countries of the region for the implementation of the principles of green economic development are energy efficiency and energy saving as the most effective, less capital-intensive and quickly feasible direction for solving energy problems, and also the measures to improve the efficiency of water use in consumption sectors is a condition for the introduction of green technologies and attracting investments - to increase crop yields, export potential and productivity of land and water, to ensure water, energy and food security of the country [8].

The experience of Turkmenistan is very interesting. The joint project of the GEF-UNDP and the Ministry of Agriculture and Environmental Protection of Turkmenistan "Support of Climate Resilient Economic Activity of Agricultural Communities in the Dry Regions of Turkmenistan" (2016-2021) provides great assistance in the implementation of adaptation practices and information dissemination of the experience of adaptation measures among land users.

As a result of its activities, the project assisted farmers and agricultural producers in reducing soil salinity, cleaning drainage channels, and installing pumps. According to the project estimates, more than 3,000 farmers and livestock breeders were able to obtain information on innovative adaptive practices as a result of the training and information work of the project.

In the rainfed lands in the foothills of the Kopetdag, the UNDP-GEF-GIZ-MEPT project "Building capacity and investments at the local level for sustainable management of the land resources" (2007-2010) introduced into the practice of agricultural producers' alternative sources of income. Part of the population of the Garavul daikhan association in the village of Kone-Gumbez was reoriented from employment in animal husbandry to crop production. [9].

\section{Conclusions}

The Central Asian region has become vulnerable to environmental challenges, such as: climate change, reduction of water resources, soil degradation, air pollution, which pose a threat to the environmental, economic and social security of the countries of the region. The 
achievements of the main goals of developing a green economy among the countries of the Central Asian region are different.

For example, for Kazakhstan, there is an increase in the share of alternative energy sources, for Uzbekistan and Turkmenistan - the rational use of water and natural resources, for Tajikistan and Kyrgyzstan - the achievement of energy independence and a transition to intensive industrialization. These activities will allow to significantly increase economic growth in these countries in the next 10-15 years. Only through the development of renewable energy sources especially the hydropower and increasing its energy efficiency and ensuring an increasing volume of energy consumption the sustainable development of the country can be guaranteed, which will correspond to the implementation of the concept of transition from a carbon economy to a green one.

The advantage of the green economy is the focus on modern energy and resource-saving technologies with low-carbon emissions, minimization of the burden on nature and creation of additional jobs, ensurance of sustainable ecological and economic development [10].

The green economy should be presented as a new economic paradigm, which will allow not only to overcome the traditional antagonism between the economic and environmental goals of modern society, but also to achieve their synergistic complementarity in order to ensure the sustainability of socio-economic development.

In the practice of agricultural production, rational watering methods such as drip irrigation and sprinkling continue to develop. [11]

Reforestation is an important tool for adaptation to climate change.

Thus, defining all the listed principles and characteristics, it is possible to determine the mechanisms for implementing the green economy in the countries of the Central Asian region:

- $\quad$ readiness for appropriate reforms in economic management;

- creation of favorable conditions for a broad participation of civil society and improvement of the mentality of the population of the region for the introduction of green elements in all spheres of life;

- rational and reasonable use of water resources (taking into account more than half of the fresh water reserves in the Central Asia);

- $\quad$ increasing resource and energy efficiency;

- production of ecologically clean agricultural products (taking into account the favorable natural and climatic conditions for the development of ecological agriculture);

- development of drinking water supply, sewerage, irrigation and drainage systems;

- $\quad$ the introduction of innovative methods of irrigation (drip, sprinkler, subsoil, etc.) based on water-, resource- and landscape-forming reclamation technologies, etc. [12]

To overcome (minimize) the dependence of the world economy on the influence of unstable environmental problems, it is necessary to intensify the transition from fossil fuels to renewable energy sources, primarily due to environmental, economic, social and political reasons. It is also advisable to increase the competitiveness of alternative energy through the widespread use of the economic mechanism of the use of natural resources and environmental protection, primarily the renewable energy sources.

In this regard, the ways to improve and develop the green economy have been identified:

- the problem of minimizing climate change in the region is the reduction and limitation of greenhouse gas emissions, the energy intensity of GDP and the expansion of the use of renewable energy sources;

- combating land degradation processes (soil erosion, salinization, desertification, etc.) in the region, aggravating processes of rational use of agricultural lands;

- biodiversity conservation (environmental protection, conservation of flora, genetic resources, regulation of transboundary movement and use of living modified organisms); 
- $\quad$ effective management of water and energy resources (integrative cooperation with the aim of completing the construction of large hydropower facilities (Kambarata HPP in Kyrgyzstan, Rogun HPP in Tajikistan);

- formation and development of a single regional energy market within the Central Asian countries on the principles of privileged partnership, cooperation and equality in relations (attracting investments, etc.)

\section{References}

1. N.A. Brovko, D.I. Dikaya, Proceedings of the of the IV International scientific-practical conference: text electronic edition, 127-132 (2020)

2. S. N. Bobyleva, P. A. Kiryushina, O. V. Kudryavtseva, Green economy and sustainable development goals for Russia: collective monograph, 15 (2019)

3. I.G. Zhivotovskaya, T.V. Chernomorova, "Green economy" as a global development strategy in the post-crisis world: Rev. coll., 11 (2016)

4. D. Zhang, M. Mohsin, A. K. Rasheed, Y. Chang, F., Energy Policy, 153 (2021)

5. T.A Selischeva, Problems of modern economy, 3 (67) (2018)

6. K. Schwab, N Davis, Proceedings of the World Economic Forum, 287 (2019)

7. U.O. Kimsanov, M.M. Davlyatova, Bull. of the Taj. Nat. Univ, 5(1), 184 (2019)

8. U.O. Kimsanov, M.M. Davlyatova, Bull. of the Tech. Univ. of Tajikistan, 83 (2017)

9. GEF-UNDP, Project "Supporting climatically sustainable economic life of agricultural communities in aroid regions of Turkmenistan", 20 (2020)

10. M. M. Mohideen, S. Ramakrishna, S. Prabu, Y. Liu, Journal of Energy Chemistry, 59, 688 (2021)

11. E. Dolgova, Neutr. Turkmen, 3 (2020)

12. U.O. Kimsanov, M.M. Davlyatova, Bull. of the Tech. Univ. of Tajikistan, 98 (2019) 